\title{
DOI 10.26886/2520-7474.2(28)2018.6
}

UDC 378.938.3

\section{DISPLAY OF PECULIARITIES OF ENGINEERING ACTIVITY}

IN PEDAGOGICAL RESEARCHES

\section{O. Ponomaryov, PhD in Technical Sciences, Full Professor}

Yu. Chebakova, PhD in Pedagogical Sciences, Assistant Professor

National Technical University "Kharkiv Polytechnic Institute", Ukraine, Kharkiv

The most widespread features of psychological and pedagogical character are considered. They are illustrative of the majority of types of engineering activity. The necessity of their appropriate account in the process of planning and carrying out pedagogical research is justified. It is shown that without this, the received results cannot be considered as rather reliable. Therefore, the researcher must understand both these features and their manifestations. It is extremely important, as engineering activity is accompanied by both positive and negative consequences. One of these features is the technocratic type of thinking typical for most engineers. The task of of pedagogics of engineering education is his overcoming and ensuring its humanistic orientation. One more of features consists in importance and necessity of development of future engineers' innovative thinking and leader potential.

Key words: pedagogical researches, engineering activity, features and manifestations, innovative character, technocratic thinking, humanistic orientation.

кандидат технічних наук, профресор, О. С. Пономарьов, кандидат педагогічних наук, доцент, Ю. Г. Чебакова Відображення особливостей інженерної діяльності в педагогічних дослідженнях/ 
Національний технічний університет «Харківський політехнічний інститут», Україна, Харків

Розглянуто найбільш поширені особливості психологопедагогічного характеру, характерні для більшості видів інженерної діяльності. Обгрунтовано необхідність їх належного урахування в процесі планування та здійснення педагогічних досліджень. Показано, що без цього отримувані результати не можуть вважатися достатньо вірогідними. Тому дослідник повинен розуміти як ці особливості, так і їхні прояви. Це вкрай важливо, оскільки інженерну діяльність супроводжують як позитивні, так і негативні наслідки. Однією з таких особливостей $\epsilon$ характерний для більшості інженерів технократичний тип мислення. Завданням же педагогіки інженерної освіти є його подолання і забезпечення гуманістичної його спрямованості. Ще одна з особливостей полягає у важливості й необхідності розвитку інноваційного мислення та лідерського потенціалу майбутніх інженерів.

Ключові слова: педагогічні дослідження, інженерна діяльність, особливості та прояви, інноваційний характер, технократичне мислення, гуманістична спрямованість.

Загальна постановка проблеми. Сьогодні має місце помітне підвищення інтересу дослідників до педагогічних проблем інженерної освіти. Загалом його слід вважати позитивним явищем, оскільки якість підготовки інженерів має безпосереднє значення для розвитку матеріальних умов суспільного життя. Але аналіз наукових публікацій і дисертаційних досліджень з педагогічних проблем підготовки інженерів свідчить, на жаль, про існування такої дилеми. 3 одного боку, більшість педагогів і психологів, які, не маючи базової інженерної освіти розглядають інженерну діяльність з позиції дещо зверхнього ставлення 
до її особливостей. У них явно відсутнє розуміння існування широкого спектру інженерних спеціальностей і необхідності досить диференційованого підходу до аналізу підготовки фахівців кожного профрілю та урахування конкретних умов їхньої майбутньої професійної діяльності.

3 іншого ж боку, частина викладачів технічних дисциплін, які отримали інженерну освіту і хочуть конвертувати набутий досвід педагогічної діяльності в підготовку кандидатських чи докторських дисертацій з педагогіки, часто не володіють відповідною науковою базою, а то навіть і понятійно-категоріальним апаратом психологопедагогічної теорії. В той же час необхідність осмислення й узагальнення досвіду навчання і особливо виховання і особистісного розвитку студентів інженерно-технічних спеціальностей набуває сьогодні надзвичайно важливого значення. По-перше, прискорення науково-технічного прогресу і скорочення часу перетворення результатів відкриттів і винаходів у технології вимагають розвитку інноваційного мислення студентів та їхнього креативного потенціалу. По-друге, важливим завданням інженерної освіти стає необхідність подолання технократичного характеру мислення, притаманного значному числу не тільки інженерів, а й викладачів вищих технічних навчальних закладів.

Ефективне розв'язання розглянутих вкрай важливих завдань пов'язане необхідністю успішного задоволення зростаючих індивідуальних і суспільних потреб людей, які, до того ж, постійно ускладнюються. Основними умовами їх розв'язання виступають розвиток продуктивних сил, насамперед технологій, та належне кадрове забезпечення, належна підготовка якого саме й покладається суспільством на систему інженерної освіти. Однак якість цієї підготовки істотною мірою залежать від змісту освіти, профресійної компетенції, 
загальної і професійної культури та педагогічної майстерності викладачів.

Системне поєднання цих чинників і його належна реалізація в цілісному навчально-виховному процесі і здатні забезпечити необхідну якість підготовки інженерів нової фрормації тільки за умови цілеспрямованого використання результатів глибоких психологопедагогічних досліджень, в тому числі й на основі урахування особливостей інженерної діяльності. Такі дослідження як збагачують дидактику вищої інженерної освіти, так і створюють орієнтири для розробки ефективних інноваційних педагогічних технологій. Отже, проблема визначення характерних особливостей професійної діяльності інженерів та їх належне урахування при проведенні психолого-педагогічних досліджень стає сьогодні однією з важливих і актуальних проблем педагогіки вищої школи. Її значення посилюється ще й через те, що сьогодні професія інженера $є$ не просто надзвичайно поширеною, але й необхідною для багатьох сфер національної економіки, науки, техніки і культури.

Слід підкреслити, що інженерній діяльності притаманна істотна суспільна значущість. Крім того, вона здебільшого носить чітко виражений колективний характер, що зумовлює необхідність формування не тільки високої професійної компетентності, а й розвитку лідерського потенціалу інженера. Адже в умовах зростання конкуренції і прискорення науково-технічного прогресу мають місце потенційно конфліктні ситуації, через які може відбуватися певне загострення міжособистісних відносин в колективі. Для їх подолання необхідна психолого-педагогічна та конфліктологічна компетенція інженерів-лідерів, формування якої потребує розуміння викладачами і студентами характерних особливостей інженерної діяльності. 


\section{Зв'язок 3 актуальними теоретичними i прикладними} завданнями слід визначати у тому, що фрормування професійної і соціальної компетентності майбутнього інженера має виходити не тільки з особливостей його майбутньої професійної діяльності, а й 3 урахування провідних тенденцій розвитку змісту й характеру цієї діяльності. Важливе місце в педагогіці вищої технічної освіти має посідати соціально-гуманітарний ії складник. Обґрунтування ж його змісту, цілей і дидактичних особливостей викладання лишається вкрай актуальною теоретичною проблемою педагогіки інженерної освіти. Її розв'язання вимагає глибокого осмислення буквально кожним викладачем відповідних дисциплін, їх змісту й місця в системі підготовки інженерів.

Важливим теоретичним і водночас прикладним завданням слід вважати і урахування в системі інженерної освіти цілей, змісту й характеру майбутньої професійної діяльності випускника, імовірних напрямків їх еволюції відповідно до логіки науково-технічного прогресу і забезпечення конкурентоспроможності фрахівця на майбутньому складному ринку праці й робочої сили. Ці аспекти і мають стати об'єктом педагогічних досліджень у сфрері інженерної освіти.

Результати цих досліджень мають робити реальний внесок у забезпечення професіоналізму й особистісного розвитку інженера, у його ставлення до своєї професії, до людей та суспільства в цілому. Водночас ці результати можуть посилити позитивні особливості інженерної діяльності, подолати чи хоча б певною мірою послабити негативні. Адже це безпосередньо позначиться на фрункціональному, технічному, економічному та екологічному рівні машин і пристроїв, у проектуванні, виробництві чи експлуатації яких він бере участь, та на рівні й характері застосовуваних ним технологій. 
Аналіз досліджень і публікацій з проблеми свідчить про ії важливість і актуальність, про іï істотну теоретичну і прикладну значущість. Підтвердженням цієї тези слугують роботи не тільки фрахівців у сфрері технічних наук, але й таких авторитетних фрілософів, психологів і педагогів, як Е. Аггаці, В. М. Бабаєв, М. О. Бердяєв, С. І. Богомолов, Т. В. Гура, М. Є. Добрускін, В. Д. Комаров, В. Г. Кремень, Б. Ф. Ломов, С. П. Мовчан, С. Московичи, Х. Ортега-і-Гассет, О. І. Половинкін, Б. Рассел, О. Г. Романовський, В. С. Стьопін, В. Ф. Халіков, О. К. Чаплигін, Ф. Юнгер та інші.

Важливі положення викладені в роботах, що стали результатом глибоких роздумів про розвиток науки, техніки і технологій в загальному контексті соціального прогресу. Як приклад, можна навести роботи В. П. Андрущенка, В. Ю. Бикова, М. 3. Згуровського, О. А. Ігнатюк, О. Е. Коваленко, І. В. Кононенка, Г. Г. Півняка, Н. В. Підбуцької, $€$ І І. Сокола, Л. Л. Товажнянського. Історію інженерної діяльності досліджують В. Г. Горохов, М. І . Дятчин, В. В. Морозов, Ф. Рапп, В. М. Скляр та інші.

Психолого-педагогічним проблемам інженерної освіти приділяють увагу Є. Є. Александров, С. Ф. Артюх, А. І. Грабченка, О. О. Євдокимова, П. К. Енгельмейєр, В. О. Моляко, С. М. Пазиніч, І. Є. Стуль, В. В. Чешев та інші.

Характерними особистісними якостями інженера С. П. Мовчан та О. К. Чаплигін вважають не тільки оволодіння технічним знанням і творчістю, а й прагнення дотримуватися норм і положень інженерної етики. На їхнє глибоке переконання, «інженерна етика концентрується на індивідуальній поведінці інженера і на виробленні етичних норм, що мають регулювати його професійну діяльність» [3, с. 62].

Розглядаючи сутність професіоналізму майбутнього інженера та процеси його становлення і розвитку, Н.В. Підбуцька аналізує існуючі 
визначення й доходить висновку, що «основним змістом діяльності інженера $є$ розробка нових та/або оптимізація існуючих інженерних рішень. Наприклад, оптимізація проектного рішення, оптимізація технології, менеджмент і планування, управління розробками і безпосереднє контролювання виробництва» [6, с. 102].

Професійна діяльність інженера зі всією необхідністю має відбуватися в певних не тільки технічних, а й моральнісних нормах. Хоча існує й інша думка. Так, А. О. Воронін абсолютно впевнений у тому, що «моральні судження про техніку майже не залежать від ії̈ розуміння онтологічні, антропологічні, соціологічні підходи оково можуть розглядати техніку морально індиферентною, шкідливою, прийнятною» [2, с. 93].

С. М. Пазиніч зі співавторами досліджуючи логіку інженерної діяльності, підкреслюють, що «забезпечення ефективності не тільки інженерної, а й будь-якої професійної діяльності сучасного фахівця вимагає від нього нового рівня і характеру мислення, які б відповідали рівню складності самої діяльності та завдань, які йому доводиться розв'язувати в процесі іiї виконання». При цьому дослідники наголошують на тому, що «характерними рисами такого мислення повинні бути системність, гнучкість, оперативність та інноваційний, нестандартний підхід до прийняття і реалізації технічних та управлінських рішень» [5, с. 252]. Інноваційна спрямованість профресійної діяльності інженера сьогодні обумовлена тими загрозами глобального характеру, які постають перед людством і ставлять під сумнів саму можливість збереження умов для нормального існування людської цивілізації на нашій планеті.

Педагогіка технічної освіти має виходити з обов'язкового урахування тих психологічних особливостей інженерної діяльності, які істотно впливають на ії результати та їх ефективність. Тут необхідно 
звернути увагу на такі специфічні проблеми, як сенс і значення інженерної етики, задоволеність інженерів своєю діяльністю, ділове міжособистісне спілкування й можливості конфліктних ситуацій. Адже не випадково Х. Хан розробляє «нову концептуальну основу наукової та інженерної етики, яка ґрунтується на доброчесності етики та позитивній психології». Автор вважає за доцільне впроваджувати ці принципи безпосередньо в навчальний процес підготовки інженерів [9, C. 441].

М. Робінсон проаналізував спектр завдань, сукупність яких і складає сенс діяльності інженера, та розподіл робочого часу на їх виконання. Водночас він цікавиться, як ці проблеми впливають на задоволення інженера своєю роботою. За даними дослідника, виконання конструкторських робіт пов'язане 3 істотною часткою технічних завдань $(62,92 \%$ часу) та соціально-спільною роботою $(40,37 \%$ часу) [10, с. 391]. Одним з перших виконав дослідження психологічних особливостей конструкторської діяльності як важливої сорери інженерної праці відомий вітчизняний вчений В.О. Моляко [4]. Його робота стала класичною, оскільки автор, інженер-механік за базовою освітою, серйозно проаналізував психологію професійної діяльності конструкторів.

Профресійна діяльність інженера відбувається у тісній взаємодії 3 іншими людьми і тому вимагає від нього розвинених комунікативних здібностей, навичок ділового спілкування. А це може призвести до конфліктних ситуацій, особливо при розбіжності підходів колег до вибору тих чи інших інженерних рішень. Системний підхід до дослідження феномену конфліктного спілкування в інженерній діяльності вдало використаний О. Г. Романовським разом 3 його співавторами для аргументованого обґрунтування необхідності забезпечення конфліктологічної компетенції інженера [7]. 
Невирішені аспекти порушеної проблеми полягають, по-перше, в тому, щоб чітко визначити психолого-педагогічні особливості інженерної діяльності та ї певним чином класифрікувати. По-друге, слід належним чином орієнтувати навчально-виховний процес на підготовку майбутніх інженерів з урахуванням особливостей їхньої майбутньої діяльності. По-третє, треба навчити їх плідно використовувати позитивні особливості цієї діяльності й долати негативні. Однак головним невирішеним аспектом проблеми постає вкрай недостатнє обґрунтування і опис проявів основних особливостей інженерної діяльності.

Метою статті визначено аналіз характерних психологічних особливостей інженерної діяльності, які необхідно враховувати в педагогічних дослідженнях з педагогіки інженерної освіти. Це тим більш важливо, оскільки ці особливості істотно впливають особистість інженера, на його профресійну діяльність та на його ставлення до неї. Мається також на увазі аналіз позитивних та негативних проявів цих особливостей та можливостей педагогічного впливу на студентів для забезпечення плідного використання позитивних, подолання, нейтралізації чи принаймні послаблення негативних проявів різних особливостей інженерної діяльності. Передбачається також показати характер урахування особливостей конкретних видів інженерної діяльності в побудові теоретичних моделей для проведення педагогічних досліджень.

Виклад основного матеріалу. Сам сенс поняття «професійна діяльність інженера» $€$ не зовсім коректним, оскільки існує надзвичайно багато різних галузей і підгалузей, цілі, зміст і характер діяльності інженерів у яких можуть істотно відрізнятися. Але спільними якостями їхньої діяльності в різних сфрерах слід вважати ії складність і відповідальність. Водночас постійно зростає число сфер суспільного 
життя, забезпечення нормального фрункціонування яких потребує фрахівців з інженерною освітою. Разом з цим зростають також і вимоги до рівня відповідності таких фахівців тим професійним і психологічним рисам, які $€$ характерними для тієї чи іншої сфери. Адже без цієї відповідності досить складно забезпечити належне виконання ними множини тих завдань і функцій, які й складають зміст і характер професійної діяльності конкретного інженера.

Характерно однак, що аналіз наукових публікацій з порушеної проблеми, а також і результати виконаних нами власних досліджень та спостережень, переконливо свідчать про об'єктивне існування цілої множини характерних особливостей інженерної діяльності, які, за великим рахунком, є інваріантними відносно конкретних її сфрер, змісту й характеру завдань і фрункцій. Аналіз цих особливостей і $є$ метою даної статті.

Перш за все слід підкреслити, що профресійну діяльність інженера можна розглядати як відкриту динамічну систему, змістом якої $\epsilon$ складна сукупність взаємодій інженера як суб'єкта цієї діяльності та зовнішнього відносно нього середовища. Як і в будь-якій діяльності, їй передує формування у свідомості суб'єкта її своєрідної моделі, або психічного образу. Ця модель допомагає людині через переживання певних психічних станів обрати раціональні способи виконання відповідної дії. Таким чином, діяльність інженера тісно пов'язана не тільки з техніко-технологічними, а й психічними процесами. Їм притаманний різний характер в залежності від складності та відповідальності тих завдань і функцій, упорядкована сукупність яких і утворює сенс діяльності інженера. Разом з тим виникає своєрідна інтерференція психологічних особливостей діяльності інженера з його особистісними характеристиками. Вона певною мірою позначається на 
його особистості й на ставленні до його професійної діяльності, на розвитку його духовно-культурного світу й системи цінностей.

Важливою особливістю професійної діяльності інженера необхідно також вважати істотне місце у їі структурі управлінських і організаторських функцій. Більш того, йому доводиться виконувати й педагогічні функції з навчання і перенавчання персоналу з метою належного оволодіння працівниками новими для них технологіями, пристроями чи системами управління ними. Тому такої важливості набуває цільова управлінська, психолого-педагогічна і соціальногуманітарна підготовка майбутнього інженера взагалі. I ця підготовка сприяє розвитку лідерських якостей інженера. Не випадково О. Г. Романовський свого часу цілком справедливо підкреслював, що «навчання потенційних лідерів за кожною конкретною спеціалізацією повинно поєднувати одночасну підготовку за обраною інженерною спеціалізацією i цілеспрямовану підготовку до майбутньої управлінської діяльності, яка становить невід'ємну складову профресійної діяльності кожного інженера» [8, с. 7].

Вибудовуючи модель освітньої і професійної підготовки майбутнього інженера, педагог-дослідник повинен мати на увазі ще таку важливу і досить характерну особливість його особистості, пов'язану 3 майбутньою фаховою діяльності, яка полягає у конкретності мислення і чіткій його спрямованості на кінцевий результат. Така безумовно важлива риса має і певні негативні аспекти. Одним з них виступає інерційність мислення та його технократичний характер. Для її подолання модель фахівця має передбачати розвиток креативності. У такому разі майбутній інженер прагнутиме шукати ефективні шляхи і способи подальшого вдосконалення техніки і використовуваних технологій, організації праці та управління виробництвом. Тим самим він здійснюватиме свій внесок у науково- 
технічний прогрес і в підвищення рівня розвитку продуктивних сил суспільства, а відтак і у зростання добробуту населення.

Розвиток креативних здібностей майбутнього інженера та інноваційний характер його мислення неминуче породжують у нього системний підхід до розв'язання своїх виробничих завдань і фрункцій та й життєвих проблем. Згодом цей підхід трансформується у системний характер мислення. В результаті студент навчається визначати і враховувати широкий спектр супутніх проблем, процесів і явищ та обмежень на можливість виконання певних дій. Тому в системі професійної підготовки інженера необхідно орієнтувати його на аналіз недоліків існуючих конструкцій і технологій та на цілеспрямований пошук шляхів і способів їх ефективного подолання. Це мають бути поліпшення масо-габаритних, економічних та екологічних характеристик і безпеки використання. Важливого значення набувають також дизайн і привабливість виробу для його потенційних користувачів.

Як і представникам багатьох інших професій, інженерам і їхній діяльності притаманна суперечність між інерційністю мислення й потребою інноваційної його спрямованості. В результаті досконалі для свого часу вироби чи технології інколи стають не просто взірцем творчості, але й певним гальмом на шляху подальшого науковотехнічного прогресу, створюють психологічні обмеження для пошуків ще більш досконалих інженерних рішень. Наслідком суперечності між інерційністю та інноваційністю мислення стає поширення стереотипних підходів до виконання конструктивних і технологічних завдань. Для подолання цієї суперечності система професійної підготовки інженерів повинна бути чітко спрямована на розвиток креативних здібностей студентів. 3 цією метою вкрай важливими уявляються завдання, пов'язані з технічною творчістю, виконання яких вимагає інноваційних 
рішень. Ці завдання активно сприятимуть підготовці студентами курсових і дипломних робіт не просто на сучасному рівні, але й на рівні винаходів, які мають захищатися відповідними патентами.

Як свідчить практика, важливою особливістю інженерної діяльності має вважатися і той фракт, що успішними звичайно виявляються дії та рішення тих інженерів, які здатні долати інерційність свого мислення, проявляти креативні здібності і спрямовувати їх на інноваційні шляхи вибору та реалізації складних і відповідальних інженерних рішень. Уміння долати інерційність мислення дає їм змогу відходити від стереотипних рішень, а його інноваційна спрямованість допомагає знаходити дійсно принципово нові можливості в процесі розробки, проектування та виготовлення продукції, у розробці матеріалів із заздалегідь заданими властивостями, створення та використання нових високих технологій. Профресійна творчість інженерів завжди поєднується 3 активністю і рішучістю, 3 відповідальністю та оцінкою впливу її результатів на людей і природу.

Варто звернути увагу ще й на таку характерну особливість професійної діяльності інженера, яка полягає переважно у його участі у спільних з іншими людьми розробках складних машин, систем чи технологій. Така особливість зумовлена істотним ускладненням як самих виробів, так і відповідних процесів їх проектування, виробництва та експлуатації. Ці процеси звичайно охоплюють великі колективи проектантів, конструкторів, технологів та виробничників, що саме по собі свідчить про значну диференціацію видів інженерної діяльності й водночас породжує множину складних організаційних і психологічних колізій. Одна з них полягає в тенденції людини дещо перебільшувати значущість свого внеску у спільну діяльності, відповідному завищеному очікуванні винагороди та розчаруванні, коли вона виявляється набагато меншою через об'єктивну (чи навіть суб'єктивну) оцінку цього 
внеску керівництвом колективу. Такі ситуації здатні погіршити ставлення інженера до своїх обов'язків.

Колективний характер багатьох видів і сфер інженерної діяльності дає приклади й інших парадоксальних проявів ії особливостей у діях та поведінці інженерів. Їх сутність пов'язана з розумінням ними тієї обставини, що цікавою, престижною і перспективною для професійного зростання є робота, що вимагає інноваційних рішень. Вона ж і добре винагороджується. Ось чому інженери прагнуть попасти до складу творчих колективів, зайнятих саме інноваційними розробками. Тут вони зростають як професіонали, отримують задоволення від роботи, підвищується їхня самооцінка і самоповага, посилюється готовність до виконання все більш складних завдань і функцій.

Складність і високий рівень потенційної небезпеки багатьох результатів інженерної діяльності - споруд, машин і транспортних засобів, технологічних комплексів тощо - вимагає від інженера розвиненого почуття своєї особистої відповідальності за можливі наслідки їх фрункціонування, за забезпечення норм безпеки. Цілком зрозуміло, що відповідальність тісно пов'язана з духовністю та моральністю інженера. Формування ж у нього цих важливих якостей $є$ одним з важливих завдань системи освіти, перш за все викладання дисциплін соціально-гуманітарного циклу, особливо психологопедагогічної його підготовки. Цю підготовку необхідно спрямовувати на цілеспрямований особистісний розвиток майбутнього інженера, на забезпечення системної цілісності його особистості, його духовності, загальної і професійної культури. Ці якості стають надійною основою пошуку ним рішень, які убезпечують використання тих виробів, які несуть потенційні загрози людині чи навколишньому природному середовищу. 
Необхідні відзначити й таку особливість професійної діяльності інженера, яка полягає в поширеній можливості подвійного використання ії результатів та в усвідомленні ним цієї можливості. Ця подвійність полягає в можливості не тільки використання інженерних рішень за своїм безпосереднім призначенням, коли вони відіграють конструктивну роль, але й у їх деструктивній здатності. Це означає реальне існування серйозних загроз життю і здоров'ю людей навколишньому природному середовищу, відіграючи деструктивну роль. Більш того, певні інженерні рішення здатні цілеспрямовано використовуватися навіть для масового ураження. Ці можливості зновтаки підкреслюють важливість виховної складової освітнього процесу, духовність і моральність професійної підготовки майбутнього інженера.

Дійсно, в таких випадках відповідальність інженера відіграє особливо важливу роль. У поєднанні з системним підходом, духовністю й моральністю професіоналізм інженера здатний виступати серйозним запобіжником, який виключає чи принаймні істотно зменшує негативні можливості деструктивного використання творчих інженерних рішень. Відповідальність інженера за свої дії й рішення постійно зростає разом із зростанням кількості і складності об'єктів, на проектування, спорудження й експлуатацію яких спрямована його діяльність і які несуть потенційну небезпеку. До них слід віднести енергоблоки теплових і атомних електростанцій, підприємства хімічної і металургійної промисловості, авіаційні й ракетно-космічні засоби.

Аналіз серйозних техногенних та антропогенних аварій, які відбуваються час від часу в тих чи інших країнах і завдають значних матеріальних втрат, а то й супроводжуються людськими жертвами, свідчить, що у більшості випадків вони стають результатом і наслідком безвідповідальності чи низького рівня професіоналізму. Саме через це виникають фратальні помилки в проектній чи технологічній документації, 
які потім призводять до виробничого браку, інколи навіть прихованого. I тільки з часом ці помилки стають причинами аварій. Як це не дивно, система інженерної освіти мало уваги приділяє фрормуванню умінь студентів виявляти можливі помилки і попереджати аварійні ситуації.

Педагог-дослідник проблем інженерної діяльності не повинен ігнорувати й такої особливості цієї діяльності, як можливість виникнення в процесі ї̈ виконання певних конфрліктів чи конфліктних ситуацій. Їх можна поділити на дві групи. Перша група охоплює потенційні конфрліктні ситуації, зумовлені розбіжністю поглядів і позицій учасників спільної діяльності при виборі найбільш ефективних рішень. Вони розв'язуються належною переконливою аргументацією, зіставленням переваг і недоліків кожного варіанту. Конфрлікти другої групи пов'язані з амбіціями, суб'єктивно перебільшеною оцінкою свого внеску у спільну справу тощо. Вони носять деструктивний характер, оскільки відволікають час та енергію учасників на безплідні суперечки замість належної реалізації їхнього особистісного творчого потенціалу.

Життєва практика свідчить, що професійній діяльності інженера може бути притаманна суперечність між індивідуальними і груповими інтересами, а отже і формами роботи в процесі виконання множини завдань і функцій. Для ії успішного подолання доцільно ще в навчально-виховному процесі системно використовувати активні методи навчання і прищеплювати студентам навички командної діяльності, яка означає принципово новий рівень взаємовідносин між учасниками спільної діяльності, ґрунтується на спільних цілях і цінностях та використовує потужний синергетичний ефрект їхньої плідної взаємодії. Цей ефекти активно сприяє успішному розв'язанню суто інженерних завдань.

Слід відверто згадати й особливість професійної діяльності інженерів, яка істотною мірою є породженням технократизму їхнього 
мислення і полягає у недостатньому урахуванні ними пріоритетної цінності людини та її інтересів, її потреб і бажань. Певне нехтування системою профресійної підготовки інженерів соціально-гуманітарною складовою освіти призводить до того, що домінантою їхньої уваги стає машина, а не людина. На думку ж В. П. Андрущенка, «історію творять люди, а не машини. Водночас людина досягає свободи, не ігноруючи роль техніки, а розумно використовуючи їі, створюючи суспільство, вільне від усіх фрорм відчуження, в тому числі й відчуження машини». За його словами, «майбутнє належить людям, які володіють машинами такою самою мірою, як і власними суспільними відносинами. Суб'єктивний чинник історичного процесу, як і його об'єктивна складова, є потужним чинником розвитку». Ми поділяємо і твердження автора, що роль цього чинника особливо посилюється на історичних переломах що «саме сьогодні суб'єктивний чинник набуває вирішального значення, перетворюється на найпотужніший чинник суспільного виробництва. Головне джерело суспільного розвитку - це люди, творчою працею, розумом та доброю волею яких створюються всі матеріальні та духовні надбання, що становлять фундамент людської культури та цивілізації» [1, c. $381-382]$.

Педагог має переконливо доводити майбутнім інженерам, що техніка і технології мають задовольняти потреби та інтереси людей. Людина, її життя і здоров'я $€$ вищою цінністю, а техніка слугує поліпшенню її життя і не повинна шкодити довкіллю. Мислення інженера як творця техніки і його діяльність мають слугувати гармонізації взаємовідносин людини і природи.

Висновки. Наведені міркування дозволяють дійти таких висновків.

1. Визначальна роль інженерної діяльності полягає у забезпеченні матеріальних умов життя людини і суспільства, у впливі 
на вибір напрямків і характеру розвитку цивілізації. Тому аналіз її особливостей постає засобом наукового прогнозування еволюції і уникнення катастрофрічних варіантів.

2. Особливості інженерної діяльності вимагають належного їх урахування не тільки в організації професійної підготовки інженерів, а й у практиці наукових досліджень з педагогіки, оскільки вони істотно впливають на саму цю діяльність й на особистісний розвиток інженера, в перу чергу на характер його профресійного мислення і реалізації креативних здібностей.

3. Результати інженерної діяльності об'єктивно здатні приносити не лише конструктивні наслідки, заради яких вона і здійснюється, але й деструктивні наслідки. Система освіти і педагогічний вплив на студента мають фрормувати у нього духовні й моральні цінності, які б створювали запобіжники можливостям використання деструктивних наслідків його майбутньої професійної діяльності.

4. Наукові дослідження $з$ педагогіки вищої школи, присвячені проблемам інженерної освіти, мають враховувати особливості інженерної діяльності та допомагати спрямовувати навчальновиховний процес на особистісний розвиток студента, на виявлення та належну реалізацію лідерського потенціалу майбутнього інженера та його креативних здібностей.

Перспективи подальших розвідок полягають у використанні отриманої інформації в системі професійної підготовки інженерів 3 метою забезпечення системної цілісності навчально-виховного процесу та особистісного розвитку і реалізації креативного потенціалу кожного студента. Вкрай важливою постає також проблема його цільової підготовки до успішного виконання психолого-педагогічних функцій його майбутньої професійної інженерної діяльності. 


\section{תimepamypa:}

1. Андрущенко В. П. Історія соціальної фрілософрії (Західноєвропейський контекст): Підручник для студентів вищих навчальних закладів / В. П. Андрущенко. - К.: Тандем, 2000. - 416 с.

2. Воронин A. А. Техника и мораль / A. А. Воронин // Вопросы философрии. - 2010. - № 4. - С. 97-101.

3. Мовчан С. П. Основи фрілософрії тахніки та технології / С. П. Мовчан, О. К. Чаплигін. - Харків: Форт, 2013. - 316 с.

4. Моляко В. А. Психология конструкторской деятельности. - М.: Машиностроение, 1983. - 134 с.

5. Пазиніч С. М. Логіка інженерної діяльності / С. М. Пазиніч, О. С. Пономарьов, Л. Л. Товажнянський. - Харків: НТУ «ХПІ», 2012. - 480 с.

6. Підбуцька Н. В. Психологічні особливості інженерної діяльності / Н.В. Підбуцька // Науковий вісник Херсонського державного університету. Серія : Психологічні науки. - 2016.. - Вип. 1 (2). - С. 101-105.

7. Романовський О. Г. Конфрліктне спілкування в інженерній діяльності / О. Г. Романовський, О. С. Пономарьов, Н. В. Підбуцька. - Харків: НТУ «ХПI», 2014. - 293 C.

8. Романовський О. Г. Підготовка майбутніх інженерів до управлінської діяльності: монографрія / О. Г. Романовський. - Харків: Основа, 2001. - 312 c.

9. Han H. Virtue Ethics, Positive Psychology, and a New Model of Science and Engineering Ethics Education / Hyemin Han // Science and Engineering Ethics. -2015. - Vol. 21. - Issue 2. - P. 441-460,

10. Robinson M. A. How design engineers spend their time: Job content and task satisfaction / Mark A. Robinson // Design studies. -2012. - Vol. 33. - Issue 4. -P. 391-425.

References: 
1. Andrushchenko V. P. Istoriia sotsialnoi filosofii (Zakhidnoievropeiskyi kontekst): Pidruchnyk dlia studentiv vyshchykh navchalnykh zakladiv / V. P. Andrushchenko. - K.: Tandem, 2000. - $416 \mathrm{~s}$.

2. Voronyn A. A. Tekhnyka y moral / A. A. Voronyn // Voprosy fylosofyy. 2010. - № 4. - S. 97-101.

3. Movchan S. P. Osnovy filosofii takhniky ta tekhnolohii / S. P. Movchan, O. K. Chaplyhin. - Kharkiv: Fort, 2013. - 316 s.

4. Moliako V. A. Psykholohyia konstruktorskoi deiatelnosty. - M.: Mashynostroenye, 1983. - $134 \mathrm{~s}$.

5. Pazynich S. M. Lohika inzhenernoi diialnosti / S. M. Pazynich, O. S. Ponomarov, L. L. Tovazhnianskyi. - Kharkiv: NTU «KhPl», 2012. - 480 s.

6. Pidbutska N. V. Psykholohichni osoblyvosti inzhenernoi diialnosti / N. V. Pidbutska // Naukovyi visnyk Khersonskoho derzhavnoho universytetu. Seriia : Psykholohichni nauky. - 2016.. - Vyp. 1 (2). - S. 101-105.

7. Romanovskyi O. H. Konfliktne spilkuvannia v inzhenernii diialnosti / O. H. Romanovskyi, O. S. Ponomarov, N. V. Pidbutska. - Kharkiv: NTU «KhPl», 2014. $-293 \mathrm{~s}$.

8. Romanovskyi O. H. Pidhotovka maibutnikh inzheneriv do upravlinskoi diialnosti: monohrafiia / O. H. Romanovskyi. - Kharkiv: Osnova, 2001. $312 s$.

9. Han H. Virtue Ethics, Positive Psychology, and a New Model of Science and Engineering Ethics Education / Hyemin Han // Science and Engineering Ethics. -2015. - Vol. 21. - Issue 2. - P. 441-460,

10. Robinson M. A. How design engineers spend their time: Job content and task satisfaction / Mark A. Robinson // Design studies. -2012. - Vol. 33. - Issue 4. -P. 391-425. 